\title{
クレブジェーラ菌の $\mathrm{K}$ 抗原に関する研究 特に $\mathrm{K}$ 凝集反応の抑制について
}

\author{
富 沢 万之 助 \\ 国立予防衛生研究所細菌部（部長 福見秀雄）
}

〔受付 : 3 月 31 日・ 1958 年〕

.著者は先に Vi 抗原について $56^{\circ} \mathrm{C} 1$ 時間の加熱を繰返 えし行い, その間游離して来る Vi 抗原量字測り, 游離 Vi 抗原の Vi 凝集反応に扮よぼす影響を報告した。今， クレプジェーラ菌群のK抗原孛生理食塩水に浮游させて みると Vi 抗原と同様に容易に游離して来る, 乙の游離 のK抗原が, 游離 Vi 抗原と同じょうにK凝集反応を抑 制するために，生菌液をもつて行つた場合下凝集反応が 現われないか又は弱度に現われて来るのではないかと考 えられるので, $100^{\circ} \mathrm{C} 1$ 時間の加熱を繰返えし行い, そ の間游離して来るK抗原量を沈降反応によつて測り，こ の游離 $\mathrm{K}$ 抗原がK凝集反応をどのょうに抑制するか, 又 ての加熱によつて游離したK抗原を除去した後の菌体は ぞのようなK抢よびO凝集反応を示すかをみてみた。

次にK抗原は容易に游離するが, 加熱温度の異なるこ そによつてどのような差異な生じて来るか, 又凝集反応 が終結した後のメヂウム中には，下抗体と游離下抗原と がごのように残存しているかをみてみた。

\section{実験方法}

菌株 : 山本菌株 (K抗原の型は不明), Kl 27 上清掞よ び沈測菌の作り方 : 20 時間培養した 1 なす型培養管に生 理食塩水 $30 \mathrm{cc}$ 加えて菌浮游液を作り，乙れを 1 時間著 沸後遠心沈溊して上清をとり,乙れを 1 回目の上清とし, 次にその沈溉菌に原容量の生理食塩水を加えて再び浮游 液を作り，その 1 部をとり，乙れを 1 回目の沈澱菌とし た, このような操作を 5 回繰返えして上清と沈澱菌とを 得た。

K O血清 : ブイヨン培養の生菌の $0.25,0.5,1.0$, $2.0 \mathrm{cc}: 4$ 回にわたつて, 5 日の間隔で家鬼耳静脈内に 注射し, 最後の注射日から 1 週間後に全採血した。

O 血清 : 寒天培地に培養した $\mathrm{O}$ 型菌て $1 \mathrm{cc}$ 約 10 億の菌 浮游液を作り, $56^{\circ} \mathrm{C} 1$ 時間加熱殺菌して前者と同様にし
て作つた。

純K血清：KO血清を $\mathrm{O}$ 型菌で 2 回吸収して作つた。 沈降反応 : 重層法により, 室温で 3 時間観察した。 凝集反応 : 抗血清は倍数稀釈してその $0.25 \mathrm{cc}$ 用い, これに $0.25 \mathrm{cc}$ 菌浮游液を加え $37^{\circ} \mathrm{C}$ の睬卵器内に 2 時間 次いで室温に 1 夜放置して成績を読んだ。

生菌液と $100^{\circ} \mathrm{C}$ および $120^{\circ} \mathrm{C} 1$ 時間の加熱菌液とで 行つた凝集反应

山本菌株の $\mathrm{K}$ 抗原の加熱による影響をみるために,

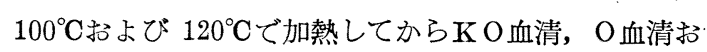
よび純K血清について凝集反応を行つてみた。その成績 を 1 表に示す。

\section{$\mathrm{K} O$ 血清に対する凝集反応}

生菌液および $100^{\circ} \mathrm{C} 1$ 時間の加熱菌液では 20 倍まで凝 集するに過ぎない, $120^{\circ} \mathrm{C} 1$ 時間の加熱菌液では 2560 倍 まで凝集するようになる, これは次の○血清の項で判る ようにO凝集価である, 所で $100^{\circ} \mathrm{C} 1$ 時間加熱後の沈筑 菌では 160 倍まで強く凝集するょうになる，てれはO血 清に㠜集しないととからK凝集価であるととが判る。

\section{O血清に対する凝集反応}

生菌液と $100^{\circ} \mathrm{C} 1$ 時間の加熱菌液掞よびその沈溉菌は 何れも20倍陰性の成績を示す。 $120^{\circ} \mathrm{C} 1$ 時間の加熱菌液 は2560倍まで凝集する, その沈溉菌に原容量の食塩水を 加えて再び $120^{\circ} \mathrm{C} て ゙ 1$ 時間加熱したものとその 沈溉菌 は, 1 回加熱後の沈䬺菌と同様に強く5120倍まで凝集す るようになる。

TOMISAWA Mannosuke: Studies on the $\mathrm{K}$ antigens of Klebsiella strains especially on inhibition of $\mathrm{K}$ agglutination. National Institute of Health of Japan - Jap. J. of Bact., 13 (8) , 734-739, 1958. 


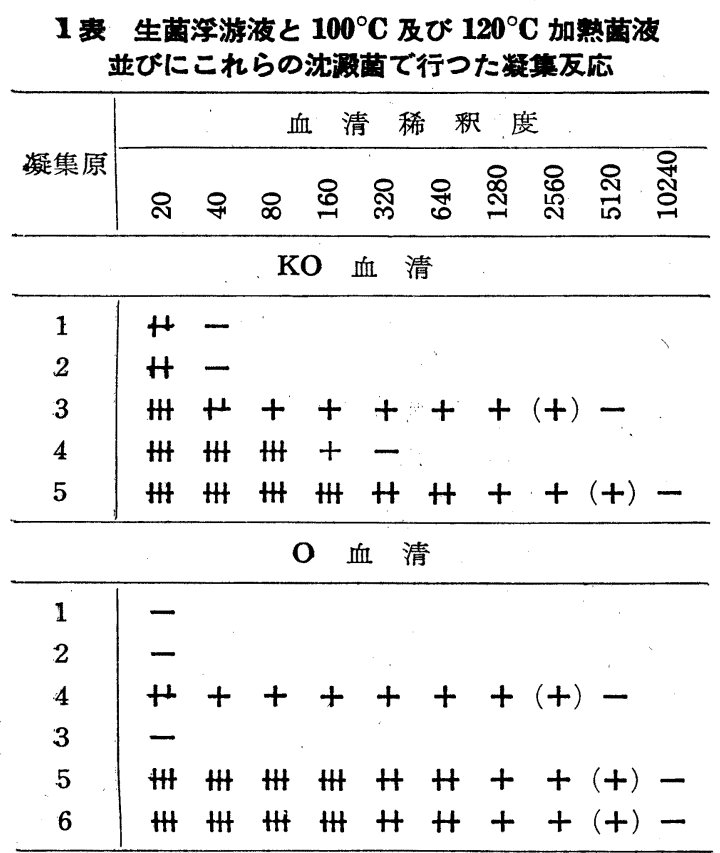

純 $\mathrm{K}$ 血清

\begin{tabular}{|c|c|}
\hline $\begin{array}{l}4 \\
5\end{array}$ & $\bar{H}+++-$ \\
\hline & $\begin{array}{l}\cdots \cdots \text { 生菌浮游液 } \\
\cdots \cdots 100^{\circ} \mathrm{C} 1 \text { 時間加熱菌液 } \\
\cdots \cdots 2 \text { の沈䬦菌 } \\
\cdots \cdots 120^{\circ} \mathrm{C} 1 \text { 時間加熱菌液 } \\
\cdots \cdots 4 \text { の沈搌菌 } \\
\cdots \cdots 120^{\circ} \mathrm{C} 1 \text { 時間 } 2 \text { 回加熱の沈澱菌 }\end{array}$ \\
\hline & 純K血清に対する凝集反応 \\
\hline
\end{tabular}

KO血清ではK凝集反応とO凝集反応とが重なり合つ て現われるので, 純 $\mathrm{K}$ 血清について凝集反応を行つてみ た。 $120^{\circ} \mathrm{C} 1$ 時間の加熱菌液では 20 倍陰性の成績を示す が, その沈溉菌は反応度とそ弱いが 160 倍まで凝集する ょうになる，その沈溉菌を 含塩水化再浮游さして再び $120^{\circ} \mathrm{C}$ で加熱するときは，その沈溉菌はすはや純 K 血清 には凝集しなくなる。

$100^{\circ} \mathrm{C} 1$ 時間加熱処置を 5 回緑返えして得た上清と沈 澱菌とて行つた沈降反応と凝真反応

$100{ }^{\circ} \mathrm{C} 1$ 時間の加熱菌液で K 凝集反応を行つてみる そ,その凝集価は生菌液の場合と同じであるが,その沈溉 菌では反応度も強く凝集価も高く現われることが判つた ので, $100^{\circ} \mathrm{C} 1$ 時間の加熱操作を 5 回絽返えして得た沈 測菌で凝集反応を行つてみた。その成績を 2 表に示す。
2 表 $100^{\circ} \mathrm{C} 1$ 時間の加熱を 5 回䋱返えして 得た沈澱菌で行つた凝集反応

\begin{tabular}{|c|c|c|c|c|c|c|c|c|c|}
\hline \multirow{2}{*}{$\begin{array}{c}100^{\circ} \mathrm{C} \text { 加熱 } \\
\text { 沈澱菌 }\end{array}$} & & & 血 & 清 & 稀 & 釈 & 度 & & \\
\hline & ล & 아 & $\infty$ & 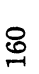 & స్లె & 융 & 怘 & 오 & 蜍 \\
\hline
\end{tabular}

$$
\text { KO , 血 清 }
$$

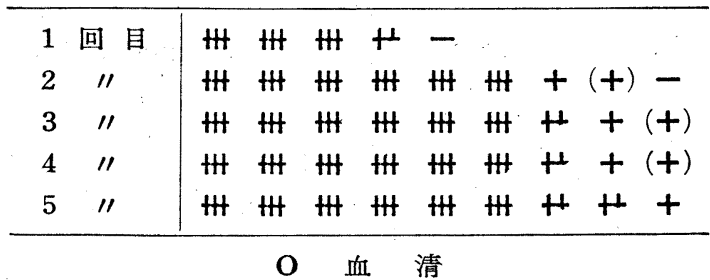

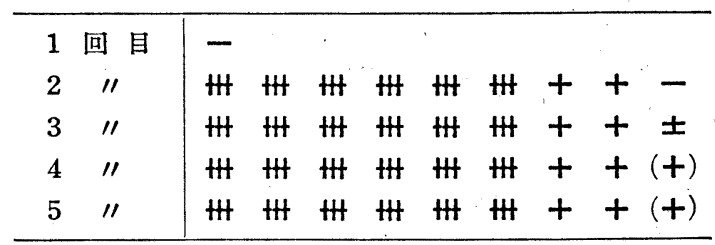

純 $\mathrm{K}$ 血清

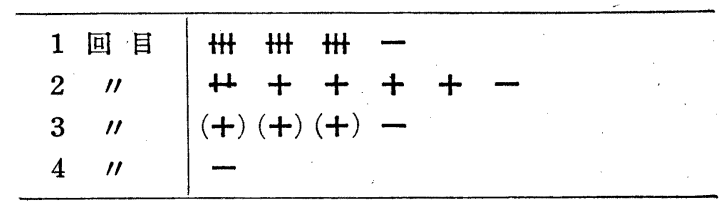

K O 血清に対する凝集反応

1 回目の沈溉菌は 160 倍まで強く凝集する。2 回目の 沈沷菌では5120倍まで凝集するようになる，てれはＯ血 清掞よび純 K血清に対する成績からＯ凝集価であること が判る。3 回目以後の沈澱菌では10240 倍まて凝集する ようになる。これも勿論 $\mathrm{O}$ 凝集価である。

O血清に対する凝集反応

1 回目の沈澱菌は20倍陰性, 2 回目以後の沈澱菌て行 つた成績は，KO血清について行つたものと略々同じょ うである。

\section{純 $\mathrm{K}$ 血清に対する凝集反応}

1 回目の沈溉菌は80倍まで強く凝集する, 2 回目の沈 溉菌では反応度は弱くなるが 320 倍まで凝集する, 3 回 目の沈澱菌では更に反応度が弱くなるが尚80倍まで凝集 する，4回目以後の沈澱菌になるこK凝集反応はみられ なくなる, 即ち下抗原はそのメチウムをかえて加熱を繰 返えしてみると 3 回目まで認められる。てれに反して0 凝集反応快 2 回目吕ら現われ 3 回目頃から治く凝集す 
るようになる。

沈降反応

K抗原は豊富に含まれているので， $100^{\circ} \mathrm{C} の$ 加熱を繰 返えすととによつてどのょうに游離して来るか, 又О抗 原はどうかをみるためにK O 血清O血清㧠よび純 K血清 について沈降反応を行つてみた。その成績を 3 表示す。

3 表 $100^{\circ} \mathrm{C} 1$ 時間の加熱を 5 回綝返えして 得た上清をもつて行つた沈降反应

\begin{tabular}{|c|c|c|c|c|c|c|c|c|c|c|c|}
\hline \multirow[b]{2}{*}{ 上清 } & \multicolumn{11}{|c|}{ 上清 稀 釈 度 } \\
\hline & - & $\infty$ & $\mathscr{\imath}$ & ల్లి & छే & $\stackrel{\infty}{\underset{\sim}{*}}$ & ڤั & $\frac{N}{10}$ & ঙ્๋ & ¿ి & ஜ̊ \\
\hline
\end{tabular}

KO 血清 $(1: 10)$

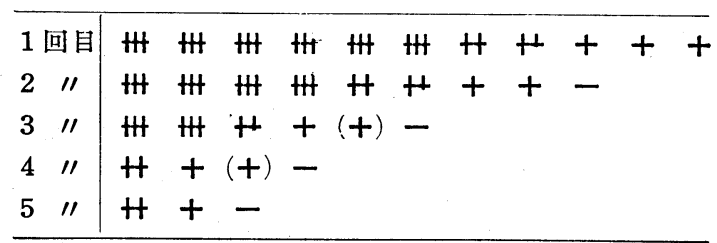

O 血清 $(1: 10)$

\begin{tabular}{lc|llllll}
\hline 1 & 回目 & $H$ & $H$ & $H$ & + & $+(+)$ & - \\
2 & $\prime \prime$ & $H$ & + & + & + & - \\
3 & $\prime \prime$ & $H$ & + & + & $(+)$ & - \\
4 & $\prime \prime$ & $H$ & $(+)$ & - \\
5 & $\prime \prime$ & + & & \\
\hline
\end{tabular}

純 $\mathrm{K}$ 血清 $(1: 10)$

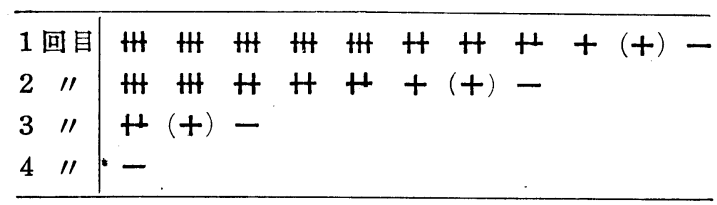

K O血清に対する凝集反応

10倍稀釈の $\mathrm{K} O$ 血清に, 上清を倍数稀釈して重層して みた。その沈降素価㹥 1 回目の上清が4096, 2 回目上清 が 512,3 回目上清が 64,4 回目上清が 16,5 回目上清 が 8 というょうに階段的に低下して来る, 殊化 1 回目拧 よび 2 回目上清において著しい。

\section{O 血清に対する凝集反忘}

10 倍稀釈の 0 血清に，上述の倍数稀釈した上清を重層 してみた, 1 回目上清は 128,2 回目扮よび 3 回目上清 は共に32, 4 回怙よび 5 回目上清は何れも 8 の沈降素価 を示す。とのように 1 回目の上清が最高の O沈降素価を. 示すととはK抗原をもつている菌株故に理解し難い。
純 $\mathrm{K}$ 血清に対する凝集反応

KO血清中に註，K抗体とO抗体とがあり，従つて2 つの沈降反応が重なつてみられるので, 純K血清につい て上述の上清安用いて沈降反応を行つてみた。1 回目上 清は2048, 2 回目上清は 256, 3 回目上清は: 8 の沈降素 洒を示し， 4 回抢よび 5 回目上清は何れも反応しなくな る。以上の成績から, $100^{\circ} \mathrm{C} 1$ 時間の加熱操作をその都 度食塩水をかえて 5 回絽返えし行つてみると, 3 回目の 上清まではK抗原が証明されるが，4回目の上清になる と認められなくなる。今，K抬よび O抗原の游離する量 も比較してるると，1回の加熱によつて大部分の K抗原 がそのメヂウム中に游離して了うょうである。O抗原は これと異なり徐从に游離し, 5 回目の上清中にも尚証明 される。次に反応の発現の速さ怙よび強さを比較してみ ると $\mathrm{K}$ 沈降反応の方は重層後直与に現われ且つ強い反応 を示すが，O沈降反応の方は発現が遅れ、且つ反忘は弱 い, 又沈降素価もK抗原の方が非常に高く現われるょう である。

\section{$22^{\circ} \mathrm{C}, 60^{\circ} \mathrm{C}$ 及び $100^{\circ} \mathrm{C} て ゙ 1$ 時間処置された 場合游離する $\mathrm{K}$ 抗原量の比較}

K抗原は Vi 抗原と同様に単に生理食塩水に浮游され たぶけで容易に游離して来るものである。今，ぞの位の 量が游離して来るものであるかをみるために，山本菌株 と K1 27 の両菌株を用いて実験を行つてみた。山本菌株 はM K O型で粘稠性であり，K1 27 KO 型で非粘稠性 である。この両菌株の 1 寒天斜面の菌量を $10 \mathrm{cc} の$ 生理食 塩水に浮游させ，乙れ寉 3 等分して， $22^{\circ} \mathrm{C}, 60^{\circ} \mathrm{C}$ おび

\section{4 表 橿々の温度で処理して得た上清の沈降素価}

\begin{tabular}{|c|c|c|}
\hline \multirow{2}{*}{$\begin{array}{l}\text { 菌 株 及 び } \\
\text { 上清の種 類 }\end{array}$} & \multirow[b]{2}{*}{ 血 清 } & 上清稀 釈 度 \\
\hline & & 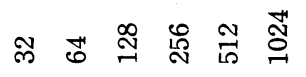 \\
\hline $\begin{array}{r}22^{\circ} \mathrm{C} \text { 上清 } \\
\text { 山本 } 60^{\circ} \mathrm{C} \text { 上清 } \\
100^{\circ} \mathrm{C} \text { 上清 }\end{array}$ & $\begin{array}{c}\text { 山 本 } \\
\text { KO 血清 } \\
(1: 10)\end{array}$ & $\begin{array}{llll}\mathrm{H} & \mathrm{H} & ++(+) \\
\mathrm{HH} & \mathrm{HH} & \mathrm{H} & + \\
\mathrm{H} & \mathrm{H}\end{array}$ \\
\hline $\begin{array}{r}22^{\circ} \mathrm{C} \text { 上清 } \\
\mathrm{Kl} 2760^{\circ} \mathrm{C} \text { 上清 } \\
100^{\circ} \mathrm{C} \text { 上清 }\end{array}$ & $\begin{array}{c}\mathrm{Kl} 27 \\
\mathrm{KO} \text { 血清 } \\
(1: 10)\end{array}$ & $\begin{array}{l}(+) \\
\mathrm{H} \\
\mathrm{H}\end{array}$ \\
\hline
\end{tabular}

$100^{\circ} \mathrm{C}$ に各 1 時間放置後すぐ遠心沈溉して上清をとり， 沈降反応を行つて游離して来た $\mathrm{K}$ 抗原量を測つてみた。 その成績を 4 表汇示す。 
山本菌株の $22^{\circ} \mathrm{C}$ 上清の沈降素価は $512,60^{\circ} \mathrm{C}$ および $100{ }^{\circ} \mathrm{C}$ の上清は共に1021の価を示し, 3 者の沈降素価は 略々等しい, 即ちこの型の菌株のK抗原は $22^{\circ} \mathrm{C}$ て容易认 而も多量に食塩水中に游離することが判る，このととは 下凝集反応沙響をおよぼして来るようである。次に $\mathrm{Kl} 27 の 22^{\circ} \mathrm{C}$ 上清は $32,60^{\circ} \mathrm{C}$ 上清は $512,100^{\circ} \mathrm{C}$ 上清は 1024の沈降素価を示す。特汇 $22^{\circ} \mathrm{C}$ 上清の沈降素価が非常

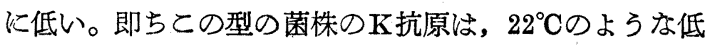
い温度では, 游離するK抗原量は前者に比して非常に少 ないようである。

\section{疑集反応終結後のメヂウム中に残存してい る $\mathbf{K}$ 抗原と $\mathbf{K}$ 抗体}

上述の実験でK抗原が室温で容易に游離の抗原となる ことが判つた。次に凝集反応の術式をみるに, 抗血清は 倍数稀釈されてゆくが, 凝集原としては同濃度の菌浮游 液が等量ずつ加えられる, それ故に, 抗血清が 或程度 稀釈（ことでは40倍以上）された所では, この游離K抗 原によつて凝集反応を起す以前にK抗体が吸収されて了

\section{5 表、疑集反応終結後の上渆で行つた沈降反応}

\begin{tabular}{|c|c|c|c|c|c|c|c|}
\hline \multirow{2}{*}{ 血 清 } & \multirow{2}{*}{ 沈 降 原 } & \multicolumn{6}{|c|}{ 血清稀 䐆 度 } \\
\hline & & 5 & 10 & 20 & 40 & 80 & 160 \\
\hline \multirow{2}{*}{ 山 本 } & 1 の上清 & - & - & H & $\mathrm{HH}$ & $\mathrm{H}$ & $\mathrm{H}$ \\
\hline & 2 の上清 & - & - & $\mathrm{HH}$ & HI & H & $\mathrm{H}$ \\
\hline 1 の上清 & 山本 & $\mathrm{Ht}$ & H & \pm & & & \\
\hline 2 の上清 & $100^{\circ} \mathrm{C}$ 上清 & HI & $H$ & - & & & \\
\hline \multirow{2}{*}{ Kl 27} & 3 の上清 & - & - & - & - & + & + \\
\hline & 4 の上清 & - & - & - & + & H & $\mathrm{HH}$ \\
\hline 3 の上清 & KI 27 & H & $\mathrm{H}$ & H & - & & \\
\hline 4 の上清 & $100^{\circ} \mathrm{C}$ 上清 & H & $\mathrm{H}$ & H & - & & \\
\hline
\end{tabular}

1 の上清…出本抗血清とその生菌液で行つた 凝集反応の上清

2 の上清……本抗血清々その $100^{\circ} \mathrm{C}$ の加熱 菌液で行つを凝集反応の上清

3 の上清…‥K1 27 抗血清とその生菌夜で行つ を凝集反応の上清

4 の上清…‥K1 27 抗血清とその $100^{\circ} \mathrm{C}$ の加 熱菌液で行つた凝集反応の上清

ろから凝集反応が現われて来ないが, 抗血清の濃い所て は, K抗体が豊富に存在しているために游離抗原（凝集 反応に用いられる程度の菌量から游離したむの) によつ て吸収しつくされないで残存しているからK菌体抗原に よつてK凝集反応が起るものと考えられる。そこで生菌
液と 1 時間の煮沸菌液とで凝集反応を行つて反応が完結 （ $37^{\circ} \mathrm{C} 2$ 時間一 1 夜水室に放置）してから遠心沈溉して 上清をとり，てれを沈降原或は抗血清として沈降反応を 行つて, 抗血清 5 倍から 160 倍までの一連の稀釈液中に 抗体と游離下抗原とがどのように残存しているかをみて みた。その成績を 5 表に示す。

山本菌株の抗血清に対して, その生菌液および煮沸菌 液で凝集反応を行い。反応完結後各試験管を遠心沈溉し て上清をとり，山本菌株の抗血清 ( $1: 10$ ) で沈降反応 を行つてみると, 1-2 管中に即与抗血清稀釈 5 -10倍ま

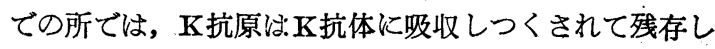
ない。K凝集反応もこの抗血清稀釈の所で一番強く反応 し特異の円板状の凝集を呈するょうである，抗血清稀釈 が20倍以上なると游離の $\mathrm{K}$ 抗原が認められるようにな る，K凝集反応もこ〉から弱まるようである。

次に Kl 27kついても上述同様にして得た上清を沈降 原として沈降反応を行つてみると。80-160 倍の所で弱 く反応するのがみられるが40倍より濃い抗血清中には游 離のK抗原が認められない。募沸菌液の場合は, 生菌液 の場合と 異なり, 抗血清40倍の 所から陽性に反応し, 80-160 倍の所では強く反応して 来るのがみられる。即 ち煮沸によつて游離抗原量が豊富になり, それが抗血清 5-20 倍つ所では抗体に吸収しつくされて了うがそれ以 上の稀釈になると抗体量が少なくなるためにK抗原が残 存しているものと思われる。

今度は反対に凝集反応を行つた各試験管の上清を抗血 清とし, 沈降原としては 1 時間煮沸菌液の上清を用いて 沈降反応を行つてみた。山本菌株の生菌液で行つた凝集 反応の場合, 抗血清 20 倍まで, 煮沸菌液の場合は, 抗血 清10倍稀釈まで抗体が証明される。Kl 27 についても同 様にして実験を行つてみたが，何れも抗血清20倍まで反 态するのがみられる。以上のように生菌液怙よび者沸菌 液で凝集反応を行つて反応完結後のメチウム中に残存し ている抗体を測つてみると殆んど同じ価を示す。その理 由凝集反応には菌体抗原が主役を演ずるのであるが抗 体消費の面からみると游離抗原も一役を演ずるので総下 抗原量を考えねばならない。

\section{$\mathbf{K}$ 凝集反底に抑制的に做く遊離 $\mathbf{K}$ 抗原}

$100^{\circ} \mathrm{C} 1$ 時間加熱菌液て凝集反応を行つてみると, 生 菌液で行つた場合と同様に20倍まで凝集するにすぎない が, 上述の加熱菌液の沈澱菌で行つてみると 160 倍まて 強く凝集するょらになる。このょうなことは Vi 抗原に おいても認められる。 
凝集反応の術式をるに, 抗血清は倍数稀釈されて次 第にうすくなるが, 凝集原として用いられる菌液は一様 な濃さである。このために, 特に血清濃度のうすい所で は, 凝集反応を起す前にK抗体が游離のK抗原によつて 吸収されて了うために凝集反応が起らなくなるものと考 えられるので, 次の実験を行つてみた。即ち山本菌株の 生理食塩水浮游液を $100^{\circ} \mathrm{C} て 1$ 時間加熱後遠心沈溉して 上清と沈溉菌とに分け, 沈溉菌を食塩水で 1 回洗つてか ら再浮游液を作り, とれを, 原液, 2 倍, 4 倍, 8 倍, 16倍に稀釈した上記の上清に等量ずつ加え，これを凝集 原としてKO血清怙よび純 K血清について凝集反応を行 つてみた。その成績を 6 表に示す。

\section{6 表 $\mathrm{K}$ 凝集反应を坜制する游離 $\mathrm{K}$ 抗原}

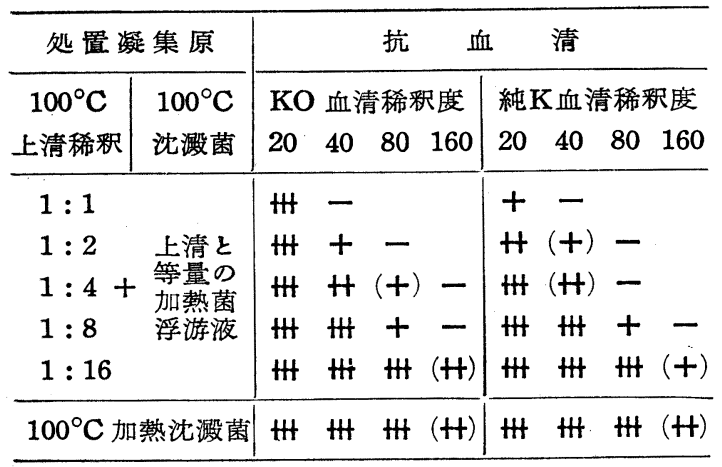

2 倍稀䣋の上清に加熱菌体を加えたもので行つた凝集 反応の成績は, 生菌液で行つたもの之略々同じである, 上清稀勫が 4 倍以上になると K凝集価が 次第に 高くな る, 上清稀䣋が16倍になると対照の $100^{\circ} \mathrm{C}$ 加熱沈溉菌と 略々等しい凝集価を示すようになる。以上の成績から游 離 $\mathrm{K}$ 抗原は下凝集反応に抑制的に働くことが判る。それ は K凝集反応を現わす以前に, 菌浮游液中にある游離 $\mathrm{K}$ 抗原によつてK抗体が吸収されて了うためであると考え られる。

\section{総括及び考䆓}

山本菌株を生理食塩水に浮游さして, $100^{\circ} \mathrm{C} 1$ 時間の 加熱操作をその都度食塩水をかえて 5 回繰返えしてみる と, 1 回目の加熱によつてK抗原の大部分は游離して了 了, 2 回目の加熱では残りの大部分が游離して来るょう であるが尚 3 回目までの上清中に証明される。これに反 して○抗原の方は 5 回以後の上清中にまでも証明され る。又下沈降反応は O沈降反応に比して早期に且つ強く 発現する，そしてK沈降素価はOのそれに比して非常に 高い価を示すようである。
K凝集反応によるときは, 加熱 3 回目までの沈測菌中 にK抗原が認められる, 生菌液ては凝集価が非常に低い が, この生菌液を $100^{\circ} \mathrm{C} 1$ 時間加熱後遠心沈澱して游離 K抗原を取り除いた後の沈溉菌で行つてみると，凝集価 が高く且つ強く現われるようになるが，O凝集反応は全 然現われて来ない。とのような成績は $56^{\circ} \mathrm{C} 1$ 時間の加熱 を繰返えして行つた腸チフス菌执よびBallerup 菌の Vi 凝集反応に执いてもみられる。即ち腸チフス $\mathrm{V}$ 型菌の56 ${ }^{\circ} \mathrm{C} 1$ 時間の加熱沈溉菌の凝集価は, 生菌液のそれに比し て非常に高く現われるようになる。但し Vi 抗原の発育 はK抗原程でないので 2 回目の加熱沈溉菌になると微弱 の Vi 凝集反応を示し, 3 回目の沈溊菌ではもはや反応 しなくなる。とれに反して,Vi 抗原の発育の良い Ballerup 菌は 5 回目の沈溉菌中にまで Vi 抗原が認められ る。以上の成績から凝集反応によるK抗原の分類も考え られるが, 然し総べての菌株がこのような成績を示すも のでなく,クレプジェーラ菌群中には， $100^{\circ} \mathrm{C}$ 加熱偟 よつて0凝集反応を呈するものもみられるので凝集反応 による分類は困難のようである。山本菌株は $100^{\circ} \mathrm{C} 1$ 時 間の加熱によつてO凝集反応を現わして来ないが， 2 回 目の加熱によつて現われて来るょうになる。Brooke は $100^{\circ} \mathrm{C}$ 亿括いて 2.5時間加熱しても尚 $\mathrm{O}$ 難凝集性である ことを報告している。 $120^{\circ} \mathrm{C} て ゙$ 加熱されると 1 時間て $\mathrm{O}$ 凝集反応が現われて来るょうになる。然しK凝集反応も 微弱ながらみられる。とれは著者の先の報告から, 一且 游離したK抗原が $120^{\circ} \mathrm{C} の$ 加熱によつて再び菌体に吸着 されためとも考えられるが，K抗原は Vi 抗原のように は吸着されないようであるから, 尚残存しているK菌体 抗原によるものと考えられる。生菌液では下凝集反応を 現わさない抗血清でも, K沈降反応によるとさは非常汇 高い価を示すので, 現在ての方法による分類法を研究中 である。

K抗原の分類法をみるに Kauffmann一派は Swelling test により，Edwards などは凝集反応によつているが, 沈降反応によるときはより簡単に下抗原の分類が出来る ように思われる。

次に処置温度によつて, 游離するK礼原量がごのよう に異なつて来るか文るるめに, 生理食塩水菌浮游液を $22^{\circ} \mathrm{C}, 60^{\circ} \mathrm{C}$ 抢よび $100^{\circ} \mathrm{C}$ 亿打いて 1 時間放置してから直 ぐ遠心沈溉して上清をとり，游離 $\mathrm{K}$ 抗原量を沈降反応に よつて測り，その成績を比較してみると，MKO型の菌 株では 3 者は何れも略从等しい沈降素価を示す。即ちこ の型のK抗原は生理食塩水に浮游された心゙けで容易に且 つ多量に游離して来るょうである。KO型の菌株では $222^{\circ}$ 
Cの処置によつて游離して来る K抗原量は前者に比して 非常に少ない。然し $60^{\circ} \mathrm{C}$ 抢よび $100^{\circ} \mathrm{C} て ゙$ 加熱されると MKO型の菌株と同様に多量に游離して来る。Kauffmann, Edwards などはK凝集反忘を $48^{\circ} \mathrm{C}, 50^{\circ} \mathrm{C}$ の恒温槽 中で行つているが，上述の実験から考えて不適当な方法 であると思われる。生菌液と 1 時間の募沸菌液とで凝集 反応を行つて反応が完結してから遠心沈溉して上清をと り，との上清中に残存しているK抗体执よび游離 $\mathrm{K}$ 抗原 を沈降反応によつて測つてみると，菌株によつても多少 異なるが抗血清の濃い所 ( 5 〜20倍) では抗体の残存し ているのが認められるが，抗血清が或程度稀釈された所 （20倍以上）では反対に游離下抗原の残存しているのが 認められる。

生菌液をもつてK凝集反応を行つた際, その価の低 いのは，K凝集反応を起す以前に沈降反応によつてK抗 体と游離 $\mathrm{K}$ 抗原とが結合し $\mathrm{K}$ 抗体が消費されるためと 考えられるので, $100^{\circ} \mathrm{C}$ の上清を倍数稀釈して，それに $100^{\circ} \mathrm{C} 1$ 時間の加熱洗滌菌体を加え, これを凝集原とし てK凝集反応を行つてみると, 上清の稀釈が進むに従つ て即ち游離K抗原の量が少なくなるにつれてK凝集価の 上昇するのがみられる。

\section{結 論}

山本菌株を生理食塩水に浮游させ, $100^{\circ} \mathrm{C} 1$ 時間の加 熱を 5 回絽返えし行つて上清と沈溉菌とに分け, その各 々について沈降反応と凝集度応をを行つてみた。1 回の
加熱で多量のK抗原が游離して了うことが判る。即ちそ の沈降素価岒2048である，2 回目上清のそれは256, 3 回 目のそれは 8 を示す，4回目の上清になるともはや認め られなくなる，而してK沈降素価はＯ沈降素価に比して 非常に高く且つその反応は速かにそして強く発現する。

次に下凝集反応についてみるに, 1 回加熱後の沈溉菌 は生菌液に比して反応度も強く凝集価も相当高く現われ るようになる。反忘度は弱くなるが尚加熱 3 回目までの 沈澱菌体に下抗原が認められる。

下抗原は食塩水中において低温度でも容易に游離す る。この游離のK抗原はK凝集反応を抑制するようであ る。

山本菌株は故湅谷博士から $\mathrm{Kl} 27$ は家畜衛験の坂崎博 士から御分与されたすのでさる，とつに厚く感謝しま す。

\section{文 献}

1) Brooke, M. S.: Acta Path. et Microbiol. Scandinav., 28, 313, 1951.

2) Edwards, P. R. \& Fife, M. A.: J. Bact., 70, $382,1955$.

3) Edwards, P. R. \& Ewing, W. H.: Identification of Enterobacteriaceae, 167, 1955.

4) Kauffmann, F.: J. Immunol.; 57, 71, 1947.

5) Kauffmann, F.: Enterobateriaceae, 2 nd. Edit., 1954.

6) Shimizu, M.: Jap. J. M. Sc. \& Biol., 5, 387, 407, 1952. 